\title{
Evolução histórica da gestão de riscos e desastres às inundações em União da Vitória, Estado do Paraná d
}

\section{Historical evolution of risk and disaster management to floods in União da Vitória, State of Paraná}

\author{
Larissa Maria da Silva Ferentz iD \\ Doutoranda em Gestão Urbana (PUC-PR) \\ Pontifícia Universidade Católica do Paraná (PUC-PR) \\ Curitiba, Paraná, Brasil \\ E-mail: ferentzengenharia@gmail.com
}

\author{
Carlos Mello Garcias \\ Doutor em Engenharia Civil (USP) \\ Universidade Católica do Paraná (PUC-PR) \\ Curitiba, Paraná, Brasil \\ E-mail: carlos.garcias@pucpr.br
}

\begin{abstract}
Resumo: Os impactos negativos resultantes de desastres nas cidades tem sido uma das maiores problemáticas enfrentadas pelos gestores locais. Por isto, eles têm incorporado a gestão de riscos e desastres em suas atividades, a fim de praticar a prevenção, mitigação, preparação, resposta e recuperação em suas áreas setoriais. $O$ objetivo desta pesquisa foi analisar a evolução histórica da gestão de riscos e desastres de União da Vitória, no estado do Paraná. O método, pesquisa bibliográfica, teve análise de planos, legislações e entrevistas. Os resultados foram organizados para abranger o antes e depois das 3 grandes inundações do município: 1983, 1992 e 2014. Com a ocorrência do evento de 1983, o município foi altamente impactado, sendo até hoje a maior mancha de inundação que atingiu a cidade. No entanto, não se acreditava que isto acontecesse novamente, e em menos de 10 anos depois, uma nova inundação atingiu União da Vitória. Percebe-se que esta nova ocorrência, voltou o olhar de diversas empresas e pesquisadores para tentar solucionar o problema do município. Dentre as medidas adotadas, está a criação do Parque Ambiental, o qual realocou centenas de famílias que viviam no entorno do Rio Iguaçu. Esta medida, auxiliou os gestores locais na inundação de 2014, onde foi observado que o histórico de inundações fortificou a população ao longo do tempo quanto a resposta e recuperação destes eventos. Além disto, ressalta-se a importância de conhecer a história local perante as principais inundações, para então compreender quão resiliente a desastres União da Vitória é atualmente.
\end{abstract}

Palavras-chave: Gestão de Riscos e Desastres. Proteção e Defesa Civil. Paraná.

\begin{abstract}
The negative impacts resulting from disasters in cities have been one of the biggest issues faced by local managers. Therefore, they have incorporated risk and disaster management into their activities in order to practice prevention, mitigation, preparedness, response and recovery in their sectoral areas. The objective of this research is to analyze the historical evolution of risk and disaster management of União da Vitória, in the state of Paraná. The method, bibliographic research, had analysis of plans, legislations and interviews. The results were organized to cover the before and after the 3 major floods of the municipality: 1983, 1992 and 2014. With the occurrence of the 1983 event, the municipality was highly impacted, and to this day it is the largest flood spot that has hit the city. However, it was not believed that this would happen again, and in less than 10 years later, a new flood hit União da Vitória. It is noticed that this new occurrence, turned the eyes of several companies and researchers to try to solve the problem of the municipality. Among the measures adopted, is the creation of the Environmental Park, which relocated hundreds of families that lived in the surroundings of the Iguaçu River. This measure helped local managers in the $2014 \mathrm{flood}$, where it was observed that the history of flooding fortified the population over time as the response and recovery of these events. In addition, it emphasizes the importance of knowing the local history in the face of major floods, so as to understand how resilient the disasters União da Vitória is today.
\end{abstract}

Keywords: Risk and Disaster Management. Protection and Civil Defense. Paraná. 


\section{Introdução}

A cada ano cresce o número de pessoas vivendo em situação de vulnerabilidade nas cidades, principalmente fruto das consequências do processo de urbanização. Tal processo tem resultado em impermeabilização do solo, canalização dos rios, ocupações irregulares e assentamentos urbanos precários, os quais agravam a situação das moradias localizadas em áreas suscetíveis a riscos. Como consequência, tem-se uma maior probabilidade de ocorrência de eventos extremos e de seus impactos negativos resultantes (MORENO; OYEYINKA; MBOUP, 2010).

Embora estas situações sejam problemas atuais, elas vêm se desenvolvendo ao longo do tempo. Enquanto que na década de 40 as áreas urbanas representavam $26 \%$, pouco mais de meio século depois esse número já chegava a $80 \%$. Dessa forma, ressalta-se que os "altos índices de densidade populacional configuram-se como uma causa significativa de riscos em locais onde a qualidade de vida, infraestrutura e serviços essenciais são escassos" (ONU, 2010, p.8).

$\mathrm{Na}$ década de 60 o número de pessoas afetadas por desastres naturais foi duas vezes maior que na anterior. Ao passo que na década de 70 teve um quadro, ainda, pior, com um número seis vezes maior nos casos de óbitos. Neste mesmo período as inundações atingiram 15,4 milhões de pessoas no mundo. Em observância a estes casos, afirma-se que os maiores números de vítimas estão relacionados tanto com os países mais pobres, quanto com as populações que se encontram em áreas de risco e em situações de vulnerabilidade social (BRUNDTLAND et al., 1987).

A partir dos anos 80 o olhar se volta para as consequências que os desastres causam nas cidades. Fato que levou a Assembleia Geral da ONU instituir o dia 13 de outubro como o Dia Internacional para a Redução de Desastres, a fim de buscar a conscientização da população, organizações e governos quanto à necessidade do desenvolvimento de programas e ações que contribuam para a prevenção e redução do risco de desastres. Por meio da prevenção, mitigação e preparação é possível diminuir as vulnerabilidades e aumentar a capacidade de antecipação e resposta quanto à ocorrência de catástrofes (PNRRC, 2017).

No Brasil os riscos de desastres se agravaram em decorrência do processo de urbanização desordenado e da falta de fiscalização perante as legislações, principalmente quanto ao zoneamento e uso e ocupação do solo. Estas situações podem ser evitadas com o apoio dos gestores municipais, a fim de se prevenir danos, prejuízos econômicos e perdas de vidas humanas. Por isto é importante que a Gestão de Riscos de Desastres (GRD) - com suas fases de prevenção, mitigação, preparação, resposta e reconstrução - seja integrada nos processos organizacionais e de decisão dos municípios, reforçando a importância quanto à prevenção dos impactos negativos resultantes destes eventos (PINHEIRO, 2015).

O cenário da gestão do risco de desastres congrega, portanto, a urgência na prevenção frente ao aumento da ocorrência e da intensidade de eventos extremos, o descompasso entre a gestão preventiva demandada pela recente legislação e a estrutura tecnocêntrica de ações corretivas da Defesa Civil, a vulnerabilidade de populações em áreas de risco e a participação social limitada à apropriação de conteúdos tecnocientíficos e comportamentos de adaptação para convivência com o risco (SULAIMAN, 2014). 
Estes fatores representam a necessidade do compromisso que os governos devem ter com as cidades, a fim de se permitir a tomada de decisões efetiva para a redução e prevenção de perdas humanas em caso de desastres. Isto pode ser realizado por meio de desenvolvimento sustentável integrado e da capacitação de pessoas mais resilientes (ONU, 2010).

O objetivo do presente artigo é analisar a evolução histórica que a gestão de riscos e desastres do município de União da Vitória teve ao longo dos anos, em decorrência às maiores e mais frequentes inundações do estado do Paraná.

\section{Gestão de riscos e desastres às inundações}

Milhões de pessoas são atingidas por ano no mundo em decorrência de desastres naturais, conforme 0 Centre for Research on the Epidemiology of Disasters (CRED). As maiores ocorrências pertencem aos eventos hídricos (inundações, enxurradas e alagamentos), que representam $42 \%$ dos registros históricos. Em seguida, estão os desastres meteorológicos (37\%), geofísicos (14\%) e climatológicos (7\%) (CRED, 2018).

Nos registros brasileiros, os eventos hidrológicos resultam nos maiores índices de exposição (67,5\%), morbidade $(63,5 \%)$ e mortalidade $(44,8 \%)$. As inundações representam 33\% das ocorrências no país, com quase 40 milhões de pessoas afetadas. Destaca-se que, desde 1990 a sua frequência tem aumentado, com as maiores ocorrências registradas nas regiões Sudeste (31,5\%), Nordeste (28\%) e Sul (22,6\%) (FREITAS et al., 2014).

Em decorrência à alta periodicidade de desastres hídricos no Brasil, a Constituição Federal de 1988, institui que é de responsabilidade da União planejar e adotar ações que assegurem a minimização de calamidades públicas, especialmente em relação às inundações. Em decorrência disso, em 2000 foi criada a Agência Nacional de Águas (ANA), a fim de se implementar a Política Nacional de Recursos Hídricos (PNRH). É seu dever promover medidas que previnam os efeitos das inundações nos Estados e Municípios.

As agências nacionais têm destacado a importância da adoção de drenagem urbana sustentável, com vistas a reduzir os impactos relacionados a alagamentos, e do agravamento de inundações e enxurradas. $O$ problema é que ainda existem muitos obstáculos relacionados à hidrologia no país, não apenas com questões de higiene e saneamento, mas também com as dúvidas quanto às competências hídricas. Seja referente aos interesses políticos de municípios que pertencem à mesma Bacia Hidrográfica, quanto à competência legislativa estadual ou federal ou ainda, em relação à atuação despreparada dos gestores para a administração das águas. São estas questões que retrocedem o desenvolvimento sustentável, sendo necessário que a gestão urbana interaja de forma ativa com a gestão dos recursos hídricos e de riscos e desastres (GALINDO, 2009).

No Paraná, são 709 casos de inundação registrados de 1980 até o início de maio de 2020. Estes desastres atingiram 273 municípios, afetando 282.750 pessoas. Em média, são 68 mil casos de desalojados, 167 mil desabrigado, 122 feridos e 32 óbitos. Ao todo, o prejuízo econômico resultante desses eventos é de 385,2 milhões de reais. Cabe destacar ainda que destas ocorrências, 44 registros obtiveram decretação de situação de emergência e 3 decretações de estado de calamidade pública (ECP) (BI-CEPDEC, 2020). 
A partir do exposto, observa-se que o estudo da ciência da hidrologia é extremamente importante para a busca de soluções relacionados aos problemas de uso da água, infraestrutura eficiente e redução dos riscos de desastre. Esta ciência estuda o comportamento hidrológico, a distribuições das águas, suas propriedades físicas e químicas, além do controle de cheias, enchentes e inundações (Figura 1) (TUCCI, 2005).

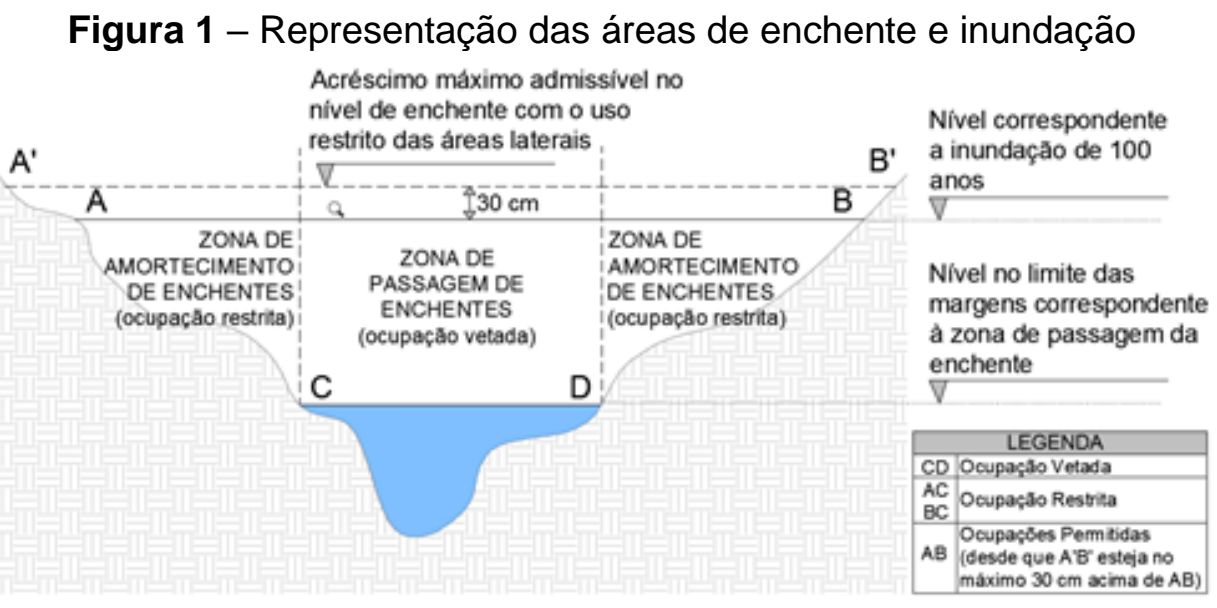

Fonte: adaptado de CH2MHILL (2002).

Em resumo, as cheias representam a elevação da vazão do corpo hídrico, o que aumenta o seu nível. As enchentes, são cheias temporárias que atingem o nível máximo do canal, até o seu leito maior. E, as inundações, são o extravasamento das águas para a planície de inundação. É importante destacar que, estas definições se referem à processos naturais. Eles são considerados desastres quando as águas atingem infraestruturas e pessoas, causando danos, perdas e prejuízos, materiais e humanos. Deste modo, considerando o leito do rio, observa-se que no desenvolvimento das cidades, o meio urbano se instala nas planícies de inundação, enquanto que as ocupações irregulares tendem a se instalar no leio maior. Ou seja, os desastres de inundação podem ocorrer, tanto nas regiões de enchente, quanto nas de planície de inundação, desde que resulte em danos e prejuízos.

Outro conceito que é alvo de dúvida na ciência hidrológica, se refere à diferença entre inundações graduais, inundações bruscas (enxurrada) e alagamento. As inundações graduais, ocorrem como resultado de chuvas prolongadas, que fazem a vazão dos rios aumentar e transbordar para as áreas planas ou de várzea. Essa situação ocorre lentamente, deixando de ser enchente com o extravasamento da cota máxima do rio. As inundações bruscas, ou enxurradas, dependem da associação entre a precipitação e as condições físicas da região. Neste caso, o escoamento ocorre de forma rápida, sendo agravado ainda, pela impermeabilização do solo e drenagem insuficiente. Por fim, os alagamentos ocorrem com a associação das chuvas e a insuficiência ou inexistência do sistema de drenagem urbano, devido à capacidade de suporte do solo quanto a infiltração das águas (CENAD, 2012).

Observa-se que sem o planejamento adequando da infraestrutura urbana, juntamente a medidas restritivas de uso e ocupação do solo, o resultado será em desastres com altos prejuízos econômicos, sociais e ambientais para os municípios. Por isto a adoção de diretrizes da Gestão de Riscos e Desastres (GRD) é essencial, sendo que suas etapas podem auxiliar os gestores locais em uma preparação e resposta mais efetiva a eventos extremos. Segundo a Política Nacional de Proteção e Defesa Civil, a GRD é formada por cinco fases, sendo prevenção, mitigação, preparação, resposta e recuperação (FIGURA 2). Cada uma das etapas é 
composta por medidas corretivas ou prospectivas, ou seja, ações realizadas sobre riscos existentes ou, quando eles são identificados durante o planejamento (FURTADO, 2012).

A etapa de prevenção, consiste na identificação dos riscos, por meio da caracterização do município; desenvolvimento de novas políticas e legislações; e identificação e mapeamento das vulnerabilidades e riscos locais. A mitigação visa reduzir os impactos negativos resultantes da ocorrência de eventos extremos, sejam com medidas estruturais, como a construção de barragens ou com medidas não estruturais, como a realocação de pessoas que vivem em áreas de risco. A última etapa da gestão de riscos, preparação, lida com o treinamento e capacitação dos gestores e principalmente, das comunidades, a fim de reduzir as perdas e danos durante os desastres (PINHEIRO, 2017).

Figura 2 - Etapas da Gestão de Riscos e Desastres

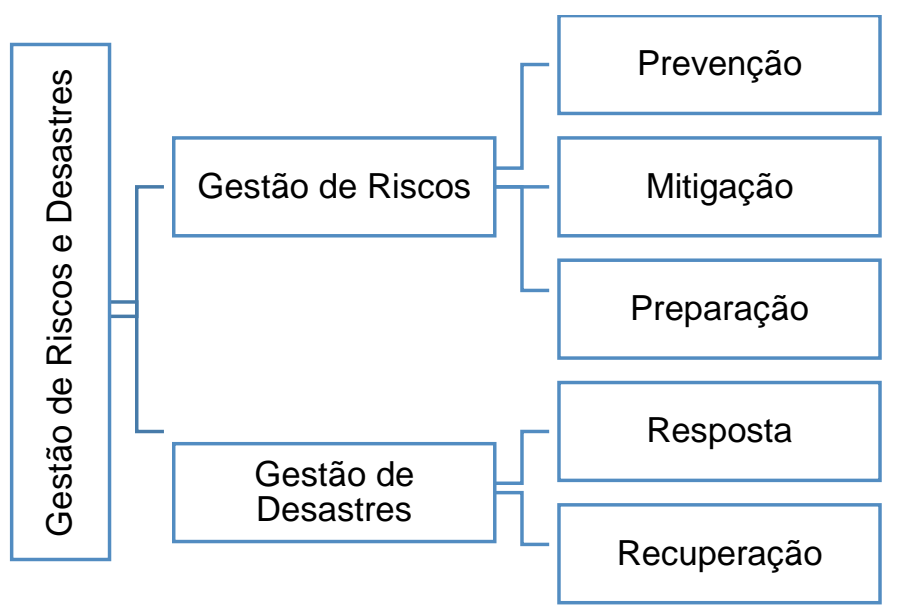

Fonte: Elaborado pelos autores.

A etapa de resposta consiste na eficiência das ações a serem realizadas durante a ocorrência de um evento extremo. Nela são avaliadas o desenvolvimento estratégico das equipes, assim como as mobilizações e organização, visando minimizar as perdas humanas. Por fim, a gestão de desastres também é composta pela recuperação, que lida com as decisões e medidas adotadas pelos gestores após o desastre. Nesta etapa, o foco é na restauração das comunidades e na adoção de estratégias para reduzir os riscos (PINHEIRO, 2017).

É importante destacar que todo este processo, previsto na Lei 12.608/12, foi pensado para auxiliar os municípios a lidarem com situações de emergência ou estado de calamidade pública em decorrência dos impactos que afetam as cidades. Para auxilinar na implementação destas etapas, foi adotado o termo resiliência. A resiliência busca a integração multisetorial, indo de encontro ao previsto pela Política Nacional de Defesa Civil. Com a sua instituição, diversas leis foram alteradas, a fim de se tornar parte integrante dos diferentes setores da sociedade. Desta forma, haverá uma maior organização, preparação e adaptação local, visando a redução de riscos (FOLKE et al., 2002).

A redução do risco de desastres ocorre quando políticas e medidas de minimização de vulnerabilidade são estabelecidas nos municípios, considerando as características de cada região. Cada território está sujeito a diferentes tipos de ameaça, fazendo com que os gestores tenham de adotar diferentes estratégias para que o processo seja eficiente e também, participativo. Deste modo, para reduzir os riscos, é necessário treinar as comunidades para o enfrentamento das ameaças. Apenas com integração entre a população, áreas setoriais e 
organizações será possível implementar a gestão de forma organizada, garantindo assim, a promoção da cultura de redução de riscos (FURTADO, 2012).

Nesse sentido, os gestores municipais são fundamentais, pois são o contato entre a população e os governantes - estaduais e da União. São eles os responsáveis por compreender as características, vulnerabilidades e ameaças em que seus munícipios estão inseridos, definindo instrumentos e diretrizes para monitorar e implementar ações. Isso resulta em eficiência no desenvolvimento estrutural e na capacidade de desempenho das articulações institucionais (MCGILL, 2001). Todo este processo se resume na capacidade que as comunidades possuem para enfrentar os riscos e ameaças, diminuindo os impactos negativos quando os desastres ocorrem. Para isto, são necessárias medidas estruturais e não estruturais, na forma organizacional, administrativa e operacional (UNISDR, 2010).

\section{Implementação da Política Nacional de Proteção e Defesa Civil em nível municipal}

A Política Nacional de Proteção e Defesa Civil (PNPDEC) foi instituída pela Lei Federal 12.608 de 2012, pelo Sistema e Conselho Nacional de Proteção e Defesa Civil (SINPDEC/CONPDEC). O seu principal objetivo é implementar a gestão de riscos e desastres nas diversas áreas setoriais do Brasil, articulando a União e o Distrito Federal com os estados e municípios. Segundo a presente lei, ela deve ser integrada às políticas de ordenamento territorial, desenvolvimento urbano, saúde, meio ambiente, mudanças climáticas, gestão de recursos hídricos, geologia, infraestrutura, educação, ciência e tecnologia e às demais políticas setoriais, com vistas à promoção do desenvolvimento sustentável.

A integração entre a gestão de riscos de desastres com todos os setores da sociedade pode ser realizada, em primeiro momento, por meio da institucionalização de uma estrutura política e legislativa. Para isto é importante que se estabeleça um quadro legislativo quanto à resiliência e redução de riscos, tendo como principais atribuições a identificação das restrições e obrigações do planejamento, das legislações e regulamentos; o aperfeiçoamento dos presentes ofícios, assim como a criação de novas leis, considerando os fundamentos da resiliência; e a atualização dos padrões até então estipulados nos diversos setores, considerando as análises de minimização de riscos (ONU, 2012).

O investimento perante estas medidas se faz necessário quando há a necessidade em se regulamentar a redução de riscos de desastres locais. É importante analisar as ações que devem ser tomadas para que não haja a interferência no alcance do objetivo (Quadro 1). Por isso, a integração entre os planos e o orçamento do governo também deve ocorrer, assim como, que se busque por incentivos externos para o auxílio na complementação de renda e na promoção das atividades (ONU, 2012). 
Quadro 1 - Planejamento de Redução de Riscos de Desastres

Construção e Planejamento de

Regulamentos que Facilitam a Redução de Riscos de Desastres Locais

Atribuições nacionais que delegam responsabilidades ao governo local para práticas seguras de construção (enquanto contribuem com conhecimento técnico especializado e recursos para implantar planos e cumprir regulamentos de construção).

Reconhecimento pelo governo local das necessidades dos pobres e responsabilidade com eles.

Planos, códigos e padrões desenvolvidos com a inclusão da perspectiva dos investidores, moradores e diversas comunidades.

Reconhecimento dos processos informais de construção e motivação para práticas seguras de construção por meio da educação e militância.
Construção e Planejamento de

Regulamentos que Impedem a Redução

de Riscos de Desastres Locais

Padrões de segurança de construção e instrumentos para posse de terra impossíveis ou inviáveis para pessoas de baixa renda.

Desigualdades de acesso à terra e moradia.

Despejos forçados ou redução de segurança no que diz respeito à posse dos habitantes de assentamentos informais.

Regulamentações que falham ao considerar as realidades de terreno, que ignoram as densidades urbanas, que proíbem a construção de pequenas habitações ou áreas de trabalho, que não permitem o uso de materiais alternativos mais acessíveis.

Flexibilidade nos quadros regulatórios para acomodar mudanças econômicas, ambientais e densidade de construção.

Fonte: adaptado de ONU (2012).

Esta estrutura pode facilitar as relações do governo com a comunidade para as tomadas de decisão, possibilitando a participação mais efetiva e multidisciplinar. Por isso, que os gestores devem realizar as prestações de contas de forma transparente e participativa, tendo sempre como principal objetivo a redução de riscos de desastres (ONU, 2012). As pessoas também se sentem mais seguras quando há uma relação entre a comunidade e os agentes de defesa civil. Estas relações podem ser mais fortes quando são elaborados projetos de atividades contínuas com a população como os Conselhos Comunitários de Segurança (CONSEGs), os programas de saúde da família e os agentes comunitários (OLIVEIRA et al., 2013).

Portanto, é imprescindível que os gestores tenham conhecimento sobre cada uma das etapas pertencentes à gestão de riscos e desastres (GRD). No Estado do Paraná, a Coordenadoria Estadual de Defesa Civil foi criada em 1972, passando a ser de reponsabilidade da Casa Militar em 1992. A atual estrutura do Sistema Estadual de Proteção e Defesa Civil (SEPDEC) é regulamentada pelo Decreto 9.557 de 2013 (Figura $3)$.

Para o monitoramento e adoção de novas medidas de mitigação de riscos, é necessária a realização de registros dos eventos que atingem os diferentes municípios do estado. Por isso, a Proteção e Defesa Civil do Paraná realiza a coleta de informações por meio dos Formulários de Informação dos Desastres (FIDE), que podem ser acessados no Sistema de Defesa Civil (SISDC) e no Business Intelligence (BI). Estes dados, criam um banco histórico com a evolução dos eventos extremos, permitindo realizar caracterização de cada município. 
Figura 3 - Estrutura do Sistema Estadual de Proteção e Defesa Civil

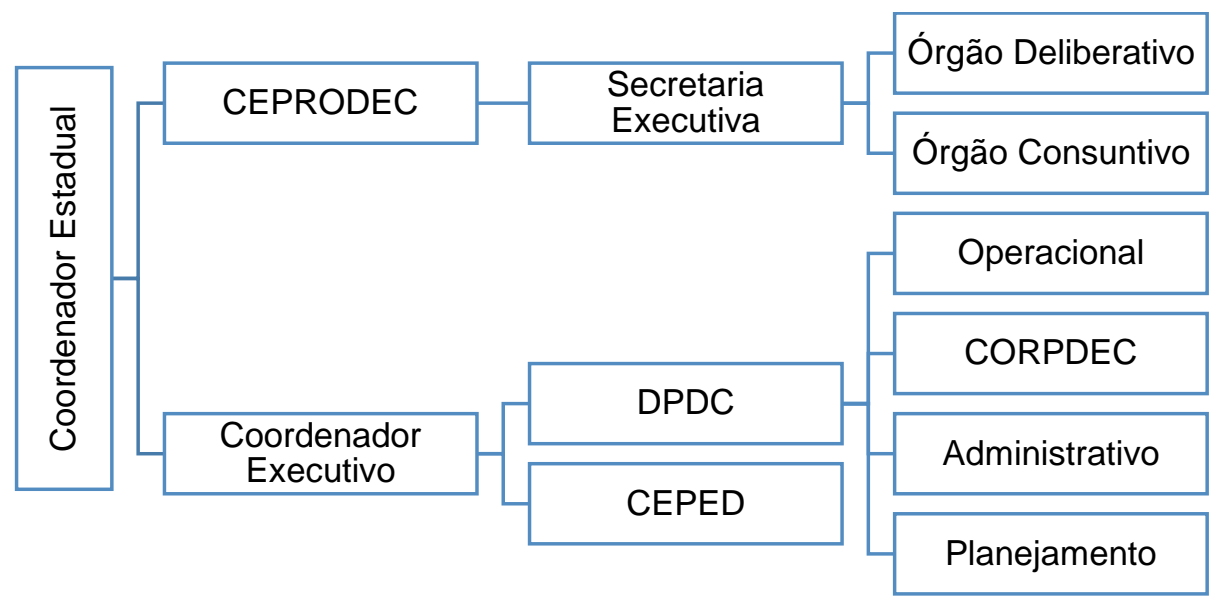

Fonte: Elaborado pelos autores.

Esses formulários obedecem a Instrução Normativa no 02 de 2016, que estabelece os critérios para determinar a necessidade de decretação de situação de emergência ou de estado de calamidade pública, assim como dos procedimentos que devem ser realizados. Outro instrumento, utilizado é o Plano de Contingência. O presente plano foi instituído juntamente à Lei 12.608/12, visando registrar o planejamento das ações e dos procedimentos que devem ser postos em prática durante a ocorrência de desastres. É nesse documento, que os gestores realizam a identificação das áreas de atenção dos municípios, e definem os contatos, para recursos materiais e humanos, necessários à resposta de eventos extremos.

A partir desse cenário, o governo reconhece a importância da criação de órgãos específicos de Proteção e Defesa Civil Municipais, a fim de coordenar as ações de prevenção, mitigação, preparação, resposta e reconstrução com profissionais qualificados e recursos necessários na ocorrência de eventos em âmbito local. A formação de um órgão oficializa o planejamento e as ações de mobilização, tornando possível também o recebimento de verbas para investir no gerenciamento dos riscos locais (OLIVEIRA et al., 2013).

Cada município deve instituir a lei de criação dos órgãos locais de Proteção e Defesa Civil, realizado também, a divulgação do Decreto de Regulamentação da Lei. Ainda é necessário a formulação de portarias com a nomeação dos membros integrantes, sendo importante que os coordenadores mantenham contato com os órgãos municipais das cidades vizinhas. Desta forma, é possível integrar os sistemas de monitoramento e alerta, e compartilhar os relatórios de risco para a formulação de ações conjuntas. Estas relações também devem ser consideradas nos níveis estaduais e federal (OLIVEIRA et al., 2013).

Dentre as atribuições do coordenador municipal de proteção e defesa civil, está a identificação das ameaças locais, a fim de elaborar planos e ações para minimizar ou eliminar os riscos de desastres. Além disto, eles também devem definir os sistemas de alarme e alerta das suas comunidades, orientando a população sobre o que fazer na ocorrência dos eventos. Ressalta-se que o coordenador deve ter capacidade técnica em gerenciamento de desastres, apresentar contato direto com o prefeito do município, tenha boas relações com os setores da administração e tenha disponibilidade integral para lidar com a atuação de desastres (OLIVEIRA et al., 2013; ONU, 2012).

Mas além do coordenador municipal, é necessário que haja uma equipe qualificada para atuar nas situações de desastre, anteriormente ou após a ocorrência. Esta equipe deve ser o apoio dos processos, seja 
pela disponibilidade de pessoas, recursos ou avaliações locais. Por isso, ela deve ser escolhida com cuidado, de maneira multidisciplinar e, preferencialmente, que já tenha experiência na área (SIMIANO, 2017). Dentre as responsabilidades da equipe, está a identificação e mapeamento dos riscos do município, sendo importante utilizar os recursos e tecnologias disponíveis, como imagens locais, satélite, projetos de avaliação, dentre outros. São essas informações que possibilitarão a redução de vulnerabilidades sociais e ambientais, e a preparação da população quanto o enfrentamento dos eventos (OLIVEIRA et al., 2013).

No entanto, não importa a quantidade de pessoas ou sua capacitação se não houver recursos disponíveis. O órgão municipal deve possuir um espaço físico específico com todos os equipamentos necessários (OLIVEIRA et al., 2013). Infelizmente, sabe-se que o atual cenário do Sistema Nacional de Proteção e Defesa Civil não vai de encontro com esta realidade, pois os recursos são escassos e a qualificação dos quadros técnicos são baixas na maioria dos municípios brasileiros. Além disso, ainda existe uma grande rotatividade de pessoas nos cargos públicos, principalmente em anos de eleição, resultando em acúmulos de cargo que não permitem a atenção total ao gerenciamento de riscos. Dessa forma, falhas de fiscalização ocorrem, aumentando as ocupações irregulares e, consequentemente, os impactos ambientais e sociais (PNUD, 2012).

Nesse sentido, é importante que pelo menos os coordenadores tenham o total domínio dos conceitos, legislações e regulamentos da área de riscos de desastres, assim como, um perfil comunicativo para uma maior facilidade de interação com a comunidade local, na gestão integrada municipal e intermunicipal e nas ações de prevenção em todas as fases do processo. Eles também devem estar sempre atualizados quanto ao tema, de modo que se possa aplicá-lo diariamente (OLIVEIRA et al., 2013; SIMIANO, 2017).

Observa-se que a redução dos riscos de desastres pode ser alcançada com a promoção de capacitações para a convivência com o risco, pois a partir do momento em que a sociedade é treinada quanto às ameaças e em como devem se comportar em situações de emergência, a redução nos danos será perceptível. Por isto, não basta investir apenas em infraestruturas e sistemas de última geração, sendo que um dos primeiros passos se iniciam com a educação da população local (OLIVEIRA et al., 2013).

A partir do momento em que as comunidades e a gestão entendam a necessidade do trabalho conjunto para a efetividade das ações de preparação e resposta, a sustentabilidade poderá ser alcançada. Afinal, a responsabilidade quanto aos desastres que ocorrem nos municípios não é única e exclusiva dos coordenadores de proteção e defesa civil. Cada pessoa possui a obrigação de contribuir com a redução dos riscos locais (ONU, 2012).

\section{Metodologia}

O presente artigo foi elaborado a partir de um estudo de caso, a fim de compreender os fenômenos históricos, as características locais e os desastres em nível político, setorial e social. A metodologia adotada é de caráter qualitativo descritivo, visando expor as medidas adotadas pelas intuições ao longo do tempo, e apresentar as evoluções da cidade a cada nova inundação (GIL, 2002). 
A determinação da amostra da pesquisa foi realizada a partir da busca pelo município do estado do Paraná que constitui o maior número de ocorrências por desastres de inundação. Deste modo, o município a ser analisado se refere à União da Vitória, localizado no sudeste do estado (Figura 4), com 32 ocorrências, 76.035 pessoas atingidas, 7 óbitos e 7 casos de situação de emergência ou estado de calamidade pública (BICEPDEC, 2020).

A fim de compreender as ações desenvolvidas ao longo tempo pelos gestores de União da Vitória frente aos desastres de inundação do município, a presente metodologia foi estruturada com levantamento fotográfico, entrevistas locais e na análise de legislações, planos e documentos. As grandes cheias chegam ao município em média a cada 10 anos e é por meio da análise histórica, com ênfase nos eventos de 1983, 1992 e 2014 (Figura 5), que se apresentará a evolução das ações quanto a Gestão de Riscos de Desastres de União da Vitória, para que só então, seja possível compreender o atual perfil de Proteção e Defesa Civil Municipal, frente aos desastres de inundação.

Figura 4 - Localização de União da Vitória

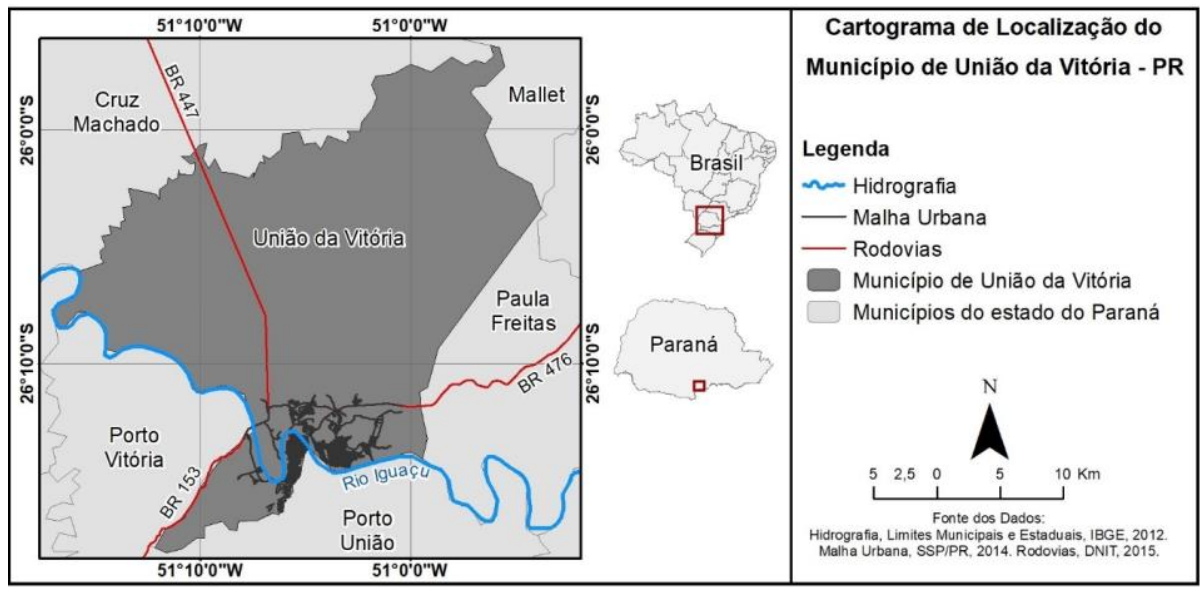

Fonte: Elaborado pelos autores.

Figura 5 - Manchas das Inundações de 1983, 1992 e 2014

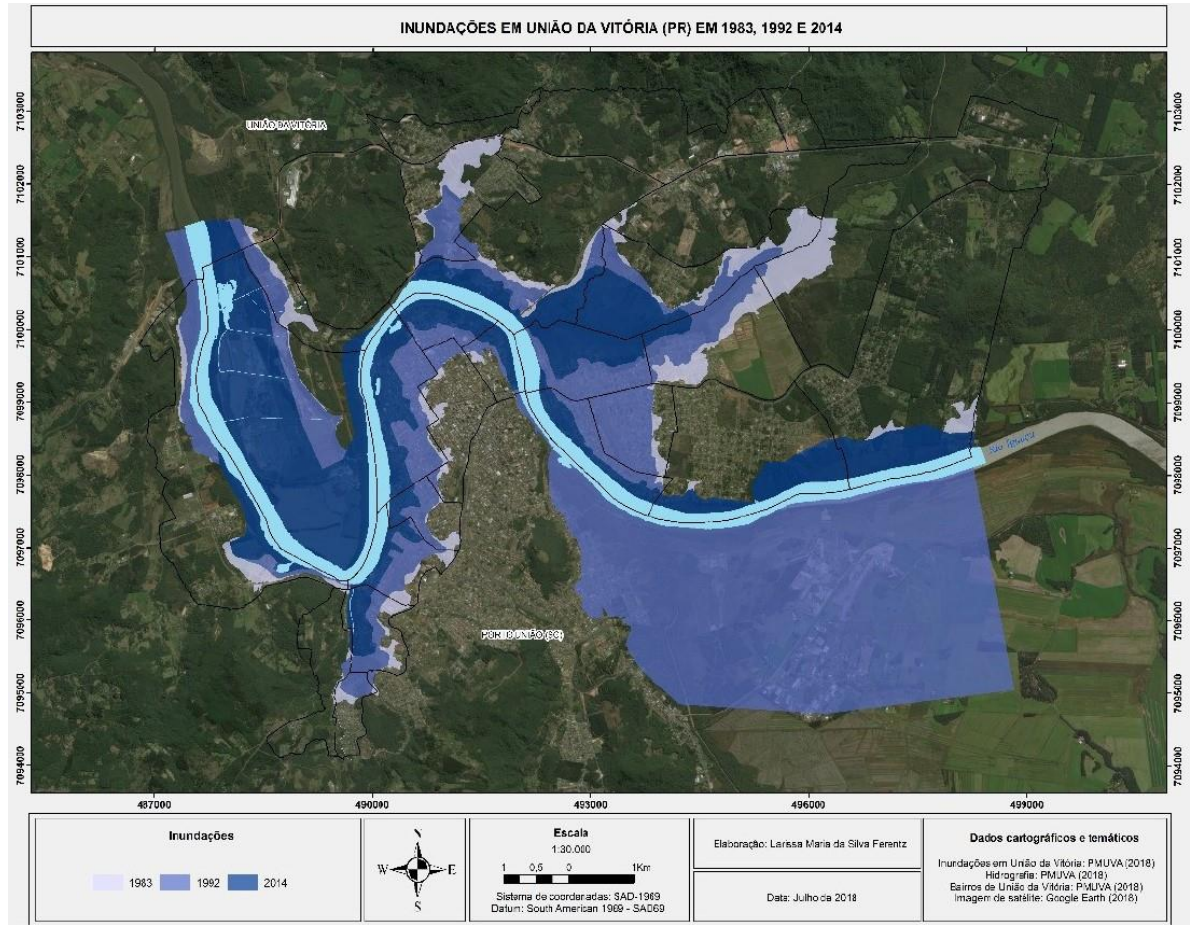

Fonte: Elaborado pelos autores a partir de PMUV (2018a).

Revista Videre, Dourados, v. 12, n. 23, jan./abr., 2020. 
Primeiramente, foram realizadas entrevistas com os gestores locais da coordenadoria municipal de proteção e defesa civil e das áreas setoriais, a fim de se coletar o máximo de informações sobre a história da cidade e de sua relação com as enchentes do rio Iguaçu. A partir do conhecimento e das experiências foi possível construir o histórico de evolução de União da Vitória, destacando as medidas estruturais e não estruturais realizadas ao longo do tempo. Cabe destacar que além das entrevistas, também foram analisadas reportagens escritas e faladas, fotografias e documentos publicados.

Além disto, a base legislativa municipal (leis, normativas e regulamentos) e os Planos existentes no município, também foram examinados para verificar a existência de aspectos relacionados aos desastres naturais e humanos. Destaque especial ao Plano de Contingência que é o instrumento de preparação elaborado para a resposta a eventos extremos. Ou seja, não só é pertencente aos processos de gestão de risco (prevenção, mitigação e preparação), como também pertence à gestão de desastres (resposta e recuperação).

\section{Resultados e discussões}

\subsection{Caracterização de União da Vitória e sua relação com a gestão de riscos e desastres}

A relação de União da Vitória com a Gestão de Riscos de Desastres se inicia com os aspectos físicos em que ele está localizado. O município é como uma represa natural, tendo em vista as características da formação rochosa do rio Iguaçu. Outro ponto que contribui com as áreas alagadiças da região, é a pouca declividade do rio por todo o trecho de União até Porto Vitória, onde o escoamento é maior (SEC-CORPRERI, 1999). No entanto, não são apenas estas propriedades que influenciam diretamente nos desastres do município, uma vez que toda a área passou por processos políticos ao longo do tempo.

O surgimento do município foi influenciado pelas tropas de gado que precisavam de um ponto de parada entre Palmas e Palmeira. A região denominada inicialmente como Porto União foi descoberta no ano de 1842, servindo também para embarque e desembarque do trânsito fluvial (SILVA, 1933). Com o fim da Guerra do Contestado, quase 30 anos depois, foi assinado o Tratado de Limites, separando o município em duas partes: Porto União, pertencente à Santa Catarina e União da Vitória, pertencente ao estado do Paraná (PMUV, 2018b). Por meio dos registros fotográficos de Claro Gustavo Jasson, sobre a Guerra do Contestado, é possível observar o início da estabilização das famílias em frente ao rio Iguaçu (Figura 6).

A problemática da urbanização quanto às inundações se deu, primeiramente, a partir desta guerra, de tal forma que União da Vitória perdeu grande parte das terras com altitude elevada nesta separação. Desde então, o desenvolvimento do município se deu de maneira progressiva, completando em 1990, o centenário da Emancipação Política. Durante muito tempo, o município manteve-se em contato com outras cidades apenas por barcos e por sua ponte férrea de 1906. Devido às dificuldades impostas pela falta de rodovias, Manoel Ribas, Governador do Estado do Paraná, autorizou a construção de uma ponte rodoviária para a cidade. A ponte dos Arcos foi inaugurada em 1944, servindo como uma oportunidade para a expansão do local (PMUV, 2018b). 
Figura 6 - Residências nas proximidades do rio Iguaçu 1912 - 2018

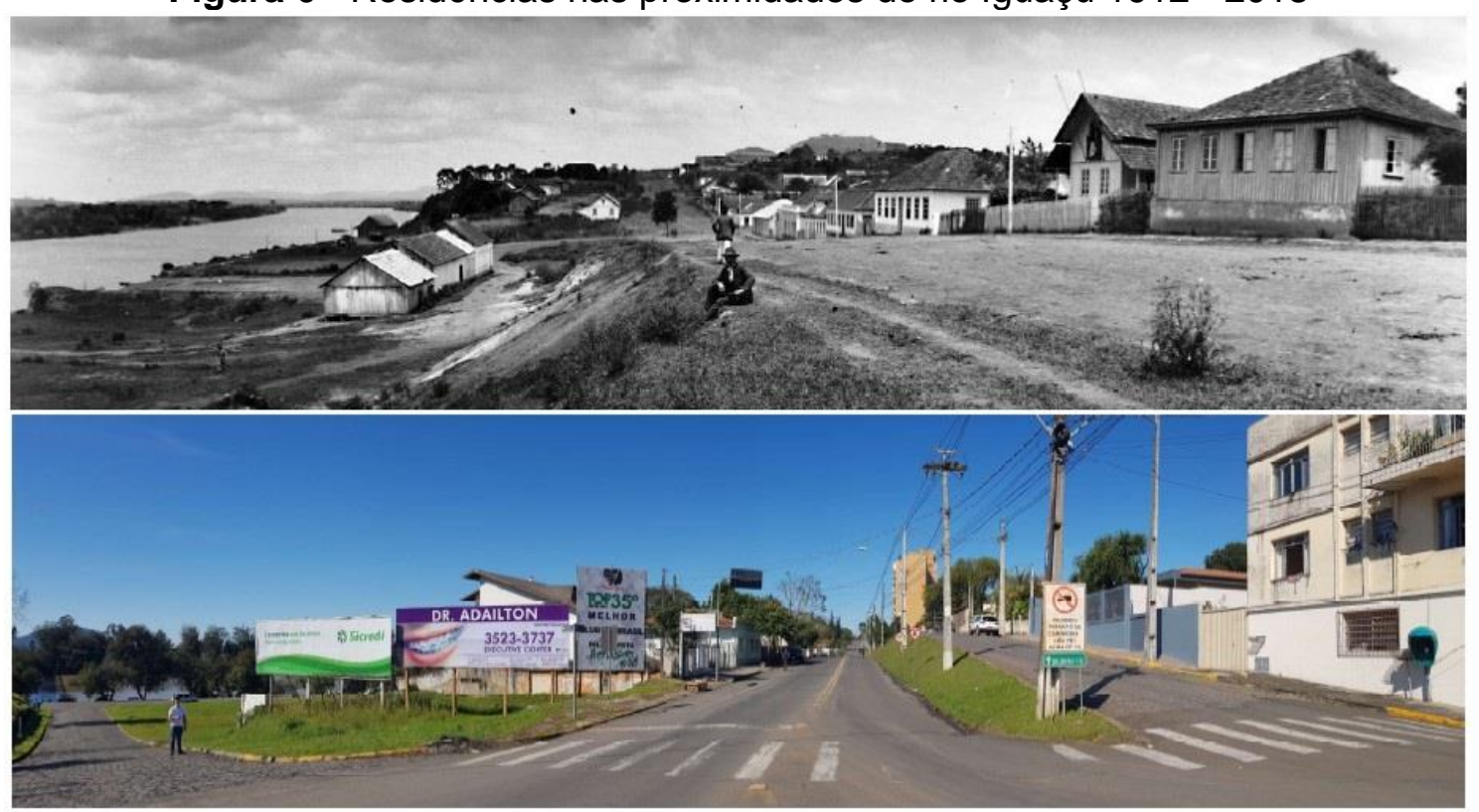

Fonte: Elaborado pelos autores, adaptado parcialmente de Jansson (1912).

Durante a construção da ponte, foi realizado o aterramento dos terrenos no entorno da Avenida Manoel Ribas, resultando no início da urbanização da cidade com a ocupação das margens do rio Iguaçu. Porém, este não foi o único motivo que influenciou a instalação de residências e comércios locais. No ano de 1952, transferiram o Colégio Túlio de França para as proximidades da Ponte, com o intuito de valorizar a região. Este fator contribuiu para o crescimento do bairro por meio de aterramentos cada vez mais próximos ao rio (MALSCHITZKY, 2018).

Ao observar o Marco das Cheias do Rio Iguaçu, tem-se a presença histórica de grandes enchentes em 1891, 1905, 1911 (SILVA, 1933), 1935, 1957 e 1970 (FRANÇA, 1983). Após este período, até 1982, apenas inundações pequenas foram registradas. De todo modo, estas ocorrências não foram consideradas frente às decisões políticas que resultaram no povoamento das partes planas, próximas ao Iguaçu. Com este fato é possível afirmar que não só as pessoas se esqueceram das enchentes, como também os órgãos públicos competentes deixaram de olhar os acontecimentos do passado, pensando apenas no progresso futuro da cidade (SEC-COPPRERI, 1999).

Foi esta "falsa sensação", de que as cheias não alcançariam maiores volumes, que resultou no maior impacto sofrido pela população de União da Vitória em julho de 1983 devido a ocupação das áreas ribeirinhas (SEC-CORPRERI, 1999). A partir desta década, a frequência e a intensidade das inundações têm se mostrado de forma padronizada, com grandes cheias a cada 10 anos, médias a cada 3 e as menores anualmente (NHOATO, 2018).

Até o ano de 1982 ocorriam pequenas inundações no município, porém, em um período de 10 anos posteriores, o prejuízo econômico chegou a 160 milhões de dólares. A principal causa levantada na época para justificar a frequência e intensidade dos desastres foi a construção da barragem de Foz do Areia, localizada a $27 \mathrm{~km}$ da cidade (TUCCI, 2013). Entretanto, hidrelétricas bem projetadas podem auxiliar na regulação do volume de água dos rios, o que volta o olhar para o crescimento populacional de uma área de cheias. O evento de 1983, o qual resultou 3 perdas humanas, inundou a cidade quase por completo (Figura 7). 
Figura 7 - Escoamento normal (à esquerda) e Inundação de 1983 (à direita)

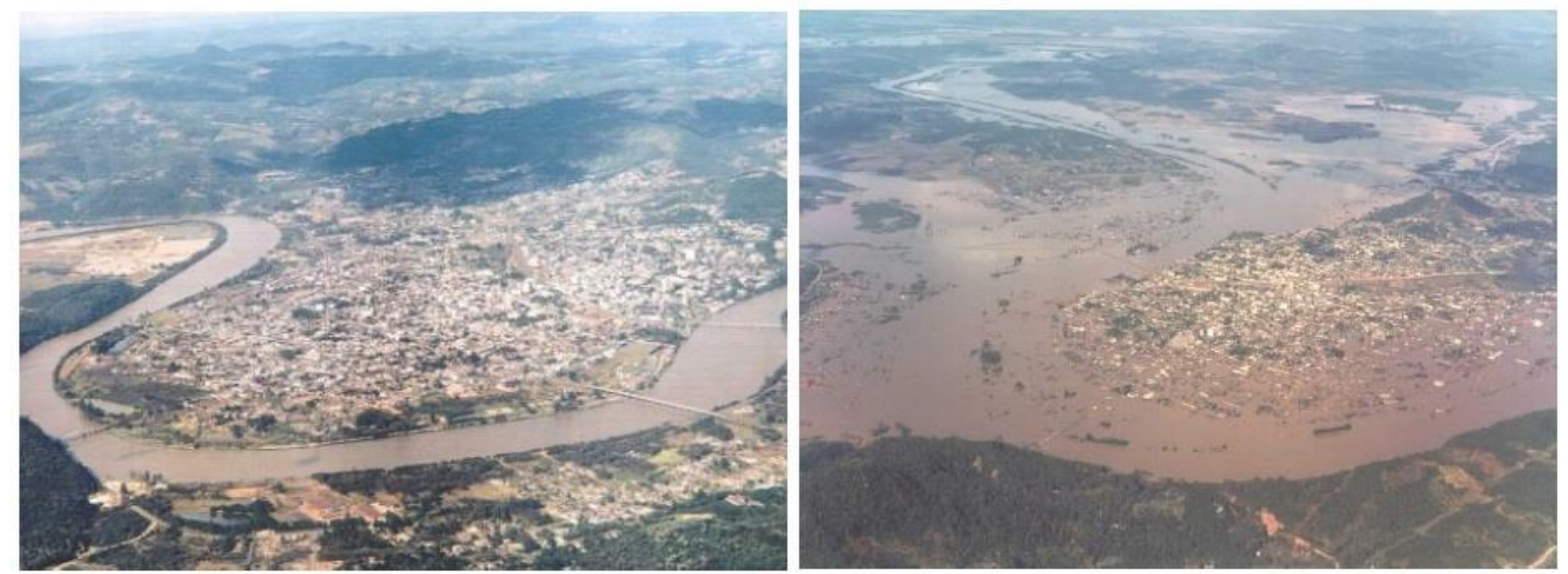

Fonte: Tucci (2013).

As chuvas de julho de 1983 resultaram em uma carga hídrica adicional de $800 \mathrm{~mm}$, o que é equivalente a 6 meses de precipitação na região (WOEHL, 2013). O nível do rio teve seu pico (com mais de 10 metros) no meio da noite. O que evitou ter sido uma tragédia muito maior foi o trem que passou apitando para acordar as pessoas e os bombeiros que dirigiam pelas ruas com as sirenes ligadas (NHOATO, 2018).

Mais de $80 \%$ da cidade ficou submersa com a inundação (FRANÇA, 1983). As pessoas tiveram de permanecer em escolas e pavilhões de igreja, enquanto donativos chegavam do Brasil inteiro, pois os únicos meios de locomoção para sair da cidade eram os barcos, helicóptero ou a estrada de ferro (NHOATO, 2018). Destaca-se que não apenas a área urbana ficou inundada, como também as áreas rurais perderam toda a plantação durante os períodos de chuva e ficaram ilhados, sem comida e sem remédio, por não terem acesso à cidade. Foi só após a construção de trilhas por dentro da vegetação que foi possível conseguir mantimentos para os agricultores (PRZYSIEZNY, 2012).

Com um prejuízo de quase 80 milhões de dólares, muitas das empresas ainda sentem os efeitos por não terem conseguido recuperar seu capital para realização de investimentos (SEC-CORPRERI, 1999). A enchente levou 60 dias para baixar por completo. Este fator está relacionado a característica do Rio Iguaçu, sendo plano de sua nascente até $16 \mathrm{~km}$ a jusante de União da Vitória. Com isto, o rio sobe rapidamente e demora muito tempo para baixar, levando de 30 a 60 dias conforme a enchente (FRANÇA, 1983; NHOATO, 2018).

Após 1983, foram registradas 11 cheias do rio Iguaçu de pequeno porte até chegar o ano de 1992 (SECCORPRERI, 1999). Enquanto em 1983 o rio Iguaçu alcançou 10,42 metros com chuvas de 800 mm, em 1992 a inundação voltou a aparecer com $280 \mathrm{~mm}$ fazendo com que o nível do rio subisse rapidamente e atingisse a marca dos 9,80 metros (CAMARGO CORREA; LEVASSEUR; MANTOVANI, 2014). As pessoas ficaram abrigadas em salões e prédios da prefeitura, as estradas foram interditadas devido aos desmoronamentos e $70 \%$ das madeireiras ficaram submersas com o evento. O trem era o único meio de transporte utilizado para a movimentação de voluntários e distribuição de insumos (DALPíCOLO, 1992).

Embora a inundação de 1992 tenha sido menor que a anterior, os danos foram muito parecidos. Com um prejuízo de 54,6 milhões de dólares, a enchente só baixou completamente 65 dias após o início da cheia 
(TUCCI; VILLANUEVA, 1997). Com este desastre, a população se revoltou com as informações divulgadas pelos estudos técnicos de 1983. A probabilidade de ocorrência de uma cheia de grande magnitude seria de 100 anos, porém, só foram considerados 50 anos de dados, desconsiderando as ocorrências da marca histórica de inundação da cidade (TUCCI, 2005).

Este fator motivou a criação da Sociedade de Estudos Contemporâneos - Comissão Regional Permanente de Prevenção Contra Enchentes do Rio Iguaçu (SEC-CORPRERI), no ano de 1993. Se configurando como uma Organização Não Governamental, a SEC-CORPRERI se tornou o meio de comunicação e conscientização da população frente os entes municipais, estaduais e federais.

De acordo com o levantamento de registros do BI-CEPDEC, entre os anos de 1992 e 2014 ocorreram 20 inundações em União da Vitória com duas situações de emergências em 2009 e 2013, e um estado de calamidade pública em 2014 (BI-CEPDEC, 2020). No evento de 2014 as precipitações duraram dois dias, acumulando o equivalente à média mensal de dois meses. Este volume de precipitação fez com o que o nível do rio Iguaçu chegasse a 8,13 metros, sendo comparada com a inundação de 1992, onde a proporção de chuva foi a mesma. Uma das causas que não permitiu que o rio ultrapassasse esta altura foi a barragem Foz de Areia, a qual estava com a sua capacidade bem abaixo do nível máximo (KOMARCHESQUI, 2014).

Com a cidade isolada, toques de recolher e sem previsão de normalidade, foi decretado o estado de calamidade pública. Além dos prejuízos econômicos e dos danos às infraestruturas que precisaram do apoio do Estado para serem reconstruídas, as pessoas também precisaram do atendimento do curso de Psicologia da Universidade de Contestado (UnC), de União da Vitória (HONESKO, 2014). Segundo o Código de Ética Profissional do Psicólogo, os profissionais devem prestar serviço em caso de situações de emergência, "com o objetivo de trabalhar a percepção de risco, planos de evacuação, mobilização comunitária..." (CFP, 2016, p. 34).

Embora o nível do rio tenha sido menor que nos eventos de 1983 e 1992, e apenas 40\% da cidade de União da Vitória tenha ficada submersa, o número total de afetados foi o maior de todas as inundações, passando de 12 mil pessoas (CAMARGO CORREA; LEVASSUR; MANTOVANI, 2014). Esse fator está diretamente relacionado à densidade urbana do município, que com o passar dos anos só aumentou. Com a prospecção imobiliária da região, o número de residências, comércios e indústrias cresceu $25,8 \%$ ao longo dos últimos 10 anos, atraindo mais pessoas para a região (IBGE, 2020).

Cada um destes eventos teve consequências negativas para a população, a qual reviveu as perdas de vidas, de bens materiais, além do grande prejuízo econômico para o município. Mesmo que estes números, de afetados e prejuízos, tenham sido maiores a cada ano, cada evento proporcionou ao governo uma chance para a fortificação das ações de prevenção e resposta aos desastres. Então quais mudanças foram realizadas ao longo dos anos? Entender a história se faz necessário para compreender o presente. 


\subsection{Histórico das inundações}

\subsubsection{Ações pós-evento de 1983}

O município de União da Vitória possui registros de ocorrências de desastres na Proteção e Defesa Civil do Paraná desde 1980, totalizando 66 incidentes com mais de 112 mil pessoas afetadas. Das 66 ocorrências, 32 estão relacionadas às inundações, tendo sete vidas perdidas durante a respectivas ocorrências (BICEPDEC, 2020). Com um histórico de eventos frequentes, o município teve de se preparar ao longo do tempo para o enfrentamento destes desastres, a fim de minimizar os riscos e os impactos negativos resultantes deles.

Os primeiros estudos realizados na região foram decorrentes da construção da Usina Bento Munhoz da Rocha Netto, também, conhecida como Foz de Areia. Sua construção se iniciou em 1975 até 1980, abrangendo um total de $4,59 \mathrm{~km}^{2}$ de área alagada no município de União da Vitória (menos de $1 \%$ da sua área total) em cota 742 m (CASTANHARO, 2005).

O problema desta estimativa é que foram apenas considerados os níveis do Rio Iguaçu registrados no posto pluviométrico da cidade, ou seja, no período de 1930 até 1975 (CASTANHARO; BUBA, 2008). Mas, também, houve a ocorrência de cheias em 1891, 1905 e 1911, alcançando uma vazão acima dos 4000m³/s contra os $1500 \mathrm{~m}^{3} / \mathrm{s}$ considerados na época (SILVA, 1933). Tendo em vista as incertezas quanto aos dados apresentados, foi realizado um novo estudo em 1975, resultando em uma influência de 79 cm no nível das águas de União da Vitória e não nos $33 \mathrm{~cm}$ considerados no projeto anterior, assim como na sugestão da construção de um dique (CASTANHARO, 2005; CASTANHARO; BUBA, 2008).

Embora os cálculos tenham sido corrigidos, a informação repassada era que para o nível da água ter este aumento, só seria possível se a capacidade da Usina estivesse totalmente cheia, com cota $744 \mathrm{~m}$ e com a casa de forças fora de operação. Ou seja, a probabilidade para estes fatores ocorrerem simultaneamente era quase nulo, não sendo tomada nenhuma medida de prevenção (ROCHA, 2014). Além desta correção, em 1980 foi realizado um novo estudo que também corrigiu a cota de operação de $744 \mathrm{~m}$ para $742 \mathrm{~m}$, abandonando a ideia do dique apresentado em 1975 (CASTANHARO, 2005).

Entretanto, embora os estudos tenham definido um cenário de grandes cheias como impossível, os poços pluviométricos registraram seus primeiros níveis acima da cota 744m na inundação de 1983 (CASTANHARO; BUBA, 2008). Após a ocorrência do desastre, com a maior cota já registrada, a lei $n^{\circ}$ 1.174/1981 foi revogada pela 1.271/1983, que incluiu a Coordenadoria Municipal de Defesa Civil como um Órgão Colegiado de Aconselhamento e Segurança. Pela presente lei, no artigo 33, à Coordenadoria "compete o cadastramento dos recursos disponíveis no Município, capazes de serem mobilizados na ocorrência de catástrofes ou de calamidades públicas, bem como sua pronta atuação em casos emergenciais".

No ano seguinte, 1985, a Copel atualizou seus estudos sobre a barragem de Foz do Areia, a partir dos dados de 1983. Com ele, foram alteradas as informações de vazões máximas da Usina, a frequência de chuvas, as curvas de descarga, além dos cálculos de retorno (CASTANHARO; BUBA, 2008; ROCHA, 2014). Cabe relembrar que nestes estudos a margem de retorno para a ocorrência de uma nova enchente, no porte da de 1983, seria de pelo menos 100 anos (TUCCI, 2005). 
Como uma forma de prevenção, iniciou-se a elaboração do Plano Diretor de reposicionamento das populações que foram atingidas pela inundação em União da Vitória, sendo um projeto financiado pelo governo federal em 1987. A recomendação resultante deste Plano era de que todas as residências que estivessem abaixo da cota 744,5m deveriam ser realocadas e que estas áreas deveriam ser reurbanizadas para evitar invasões e colocar novas famílias em risco.

\subsubsection{Ações pós-evento de 1992}

O Plano teve sua primeira versão publicada em 1991, porém, no ano seguinte, o município sofreu com a inundação de 1992. As pessoas se revoltaram por terem vivenciado toda a perda de 9 anos atrás novamente, sendo que os estudos afirmavam que isto não aconteceria a curto prazo (TUCCI, 2005).

Com a ocorrência desta inundação, a gestão municipal entendeu que surgia a necessidade de um grupo específico para tratar das questões de prevenção e mitigação dos efeitos destes desastres, criando assim a Comissão Municipal da Defesa Civil (COMDEC), do município de União da Vitória pela lei n 2004 de 1993.

Além da criação da COMDEC, outras legislações surgiram voltando o olhar para as áreas de risco do município, como a lei n 2236 de 1995, que cita a infraestrutura necessária para o reassentamento das famílias. Durante este período, surgiu um programa entre a Japan International Cooperation Agency (JICA) e o Governo do Estado, a fim de elaborar um Plano Diretor de recursos hídricos do Paraná - incluindo as inundações de União da Vitória. Para resolver o problema do município, a JICA analisou sete cenários distintos, combinando medidas estruturais e não estruturais (CASTANHARO, 2005).

Nos sete cenários avaliados foram consideradas as medidas de zoneamento e realocação escavação do canal e construção de dique, sendo estes analisados separadamente ou em conjunto, cinco delas foram consideradas como inviáveis economicamente. As outras duas se referem à construção apenas do dique, porém, além de ser necessária uma altura muito grande, resultando em um alto risco de projeto e execução, também necessitaria de um investimento de quase 90 milhões de dólares (CASTANHARO, 2005).

Tendo em vista o custo elevado, a construção não foi levada em diante, sendo apenas continuada a realocação das pessoas. Em 1996, a COPEL implantou o sistema de medições de vazão Acoustic Doppler Current Profiler (ADCP). Foi graças à instalação destes aparelhos que ocorreu a diminuição da dispersão de resultados, devido sua precisão nas medições (CASTANHARO; BUBA, 2008). Até os dias de hoje, a Coordenadoria Municipal de Proteção e Defesa Civil utiliza estes dados como os mais confiáveis para monitoramento dos níveis do Rio Iguaçu (NHOATO, 2018).

Em relação à legislação de 1996, foi criado o projeto casa fácil, para auxiliar a população das áreas de risco com até cinco salários mínimos. Os moradores de cotas até $748,50 \mathrm{~m}$, poderiam adequar a estrutura da residência sob pilotis, deixando a parte inferior aberta para o caso de inundações. Segundo Tucci (2005, p.230), estes "[...] são um dos mecanismos adotados para conviver com as cheias em União da Vitória. É frequente ver casas a 2 ou 3 metros do chão, geralmente do lado de outras ao nível do chão".

Durante estes anos, muitos projetos técnicos foram desenvolvidos para tentar encontrar alternativas que solucionassem os problemas das inundações de União da Vitória. No entanto, foi apenas no ano de 1999 que 
estas informações foram convertidas para a conscientização da população local. A SEC-CORPRERI, juntamente com a Secretaria do Meio Ambiente (SEMA) e o Instituto Ambiental do Paraná (IAP), elaborou a cartilha Conhecendo e Convivendo com as Enchentes, a fim de apresentar todas as propostas já desenvolvidas e sua relação com as áreas de risco da cidade. Esta foi a primeira iniciativa da gestão na conscientização dos moradores do município (SEC-CORPRERI, 1999).

A fim de apresentar os novos instrumentos de combate às inundações e mitigação dos seus impactos, a South America Technical Committee (SANTAC), World Meteriological Organization (WMO) e Global Water Pathership (GWP) realizaram em 2002 o workshop Estudo de caso de enchentes no Brasil: União da Vitória e Porto União. Os principais resultados destacados giraram em torno dos sistemas de alerta e alarme, da implantação de um Plano de Proteção e Defesa Civil, além da criação de um setor específico para a Defesa Civil nos municípios (ROCHA, 2014).

Em 2007, foi lançada uma minuta de anteprojeto de lei do Plano Diretor Municipal e de seus mapeamentos complementares, como do Uso e Ocupação do Solo. Este anteprojeto visou atender as metas do Plano em relação ao Estatuto da Cidade, tendo sua abrangência temporal até o ano de 2018. Porém, em 2012 houve a oficialização do Plano Diretor, sendo o ano em que União da Vitória apresentou um avanço legislativo em relação às áreas de risco de inundação. O Plano Diretor do Município visou identificar as áreas de risco e de vulnerabilidade ambiental e social, a fim de promover novas soluções para as cheias do Iguaçu (CAMARGO CORREA; LEVASSUR; MANTOVANI, 2014).

Os dois anos posteriores tiveram uma intensificação das medidas não estruturais de realocação de moradores em áreas de risco. A prefeitura criou em 2013 o programa Morar com Dignidade com o objetivo de realocar pelo menos 100 famílias (KOBUS, 2013). No primeiro trimestre, além das primeiras 50 famílias que receberem novas moradias, a COPEL iniciou o trabalho de recuperação destas áreas. Foram quase 8 hectares revitalizados, com cercamento, retirada de plantas exóticas e plantio de mudas nativas (COHAPAR, 2013). Logo em seguida, mais 66 famílias foram retiradas de bairros em risco e de áreas de preservação permanente (APP) e transferidas novos conjuntos habitacionais (KOBUS, 2013).

\subsubsection{Ações pós-evento de 2014}

Esta ação de revitalização das áreas de risco ficou ainda mais forte alguns dias antes à inundação de 2014, quando foi realizada uma parceria entre o governo do estado do Paraná, a COPEL e a prefeitura de União da Vitória para a criação do parque Caminhos do Iguaçu. O parque com 290 mil metros quadrados de extensão seria inteiramente projetado para ofertar uma área comunitária, com paisagismo, espaços para lazer, recreação, atividades esportivas, dentre outros (PARANÁ, 2014).

Ressalta-se que além de se apresentar como uma área de lazer para a comunidade, o presente parque tem como função principal evitar a ocupação irregular e, consequentemente, diminuir o número de pessoas em situação de risco por meio da transformação dos locais com maior probabilidade de inundação em áreas recreativas (Figura 8). Este tipo de projeto auxilia o crescimento da qualidade de vida da população local, diminuindo a vulnerabilidade social (MARANDOLA JR.; HOGAN, 2005). 
Figura 8 - Parque Linear em frente às casas
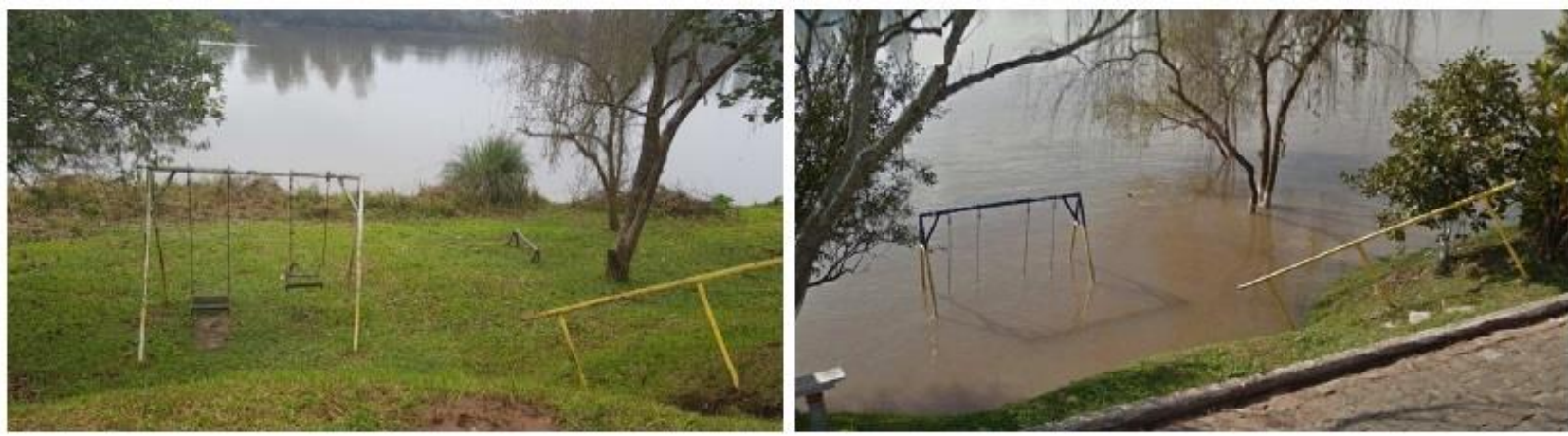

Fonte: Elaborado pelos autores, através do Google Earth (2018).

Outro ponto importante foi que a remoção dos moradores destas áreas influenciou diretamente nas ações de resposta da coordenação municipal durante o evento de inundação de 2014. Anteriormente aos programas as pessoas precisavam ser retiradas com o nível de 5 metros acima do normal e após as realocações a mobilização passou para o nível crítico de 6,5 metros (ganho de 1,5m) (MALSCHITZKY, 2018).

Após a inundação de 2014, entraram em vigor duas leis municipais, as quais, indiretamente, visavam auxiliar nas questões dos desastres da cidade. A Lei 4417/2014, criou a secretaria municipal de meio ambiente, apresentando em seu escopo, o cargo de Coordenador de Projetos de Prevenção a Desastres Naturais. A segunda Lei, 4474/2014, criou a Guarda Municipal de União da Vitória, denominada "GUARDAUV", sendo que a mesma "colaborará, quando solicitado, com tarefas atribuídas à defesa civil na ocorrência de calamidades públicas, sinistros e desastres".

Além da Guarda Municipal, o município pode solicitar a atuação de pessoas e recursos específicos na ocorrência de desastres, estando todos registrados no Plano de Contingência Municipal (PLANCON) de União da Vitória. A versão atual do Plano é a de número 33, revisão de 2018, sendo sua primeira publicação em 2014 - quase dois anos após a Lei Federal 12.608 de 2012.

Conforme o PLANCON, o capítulo que apresenta os cenários do município quanto às áreas de atenção, expõe 11 regiões sujeitas às Inundações, com um total de 4.938 pessoas em risco. As áreas de atenção são conceituadas, por Pinheiro (2015), como sendo uma delimitação que se baseia no histórico dos desastres dos municípios, a qual é apontada pelos representantes locais de Proteção e Defesa Civil. O autor (2015, p. 87), ainda, destaca que esta metodologia não é "produzida a partir da aplicação de metodologias científicas, sobre a qual, enquanto não se possuem mapeamentos de risco em escala adequada, deflagram-se as ações preparatórias iniciais do órgão de coordenação municipal [...] em caráter provisório e temporário".

Atualmente, é possível identificar diversas residências que se encontram próximas ao rio Iguaçu, em sua área de cheias. Esta situação reforça três pontos principais: (1) o zoneamento não considera as áreas de riscos de inundação; (2) falta de fiscalização municipal perante a novas construções; e (3) falta de capacitação dos moradores quanto ao risco de viver nestas áreas.

Embora no município de União da Vitória se tenham registros de inundação frequentes, já tendo passado por três grandes eventos na sua história, a relação da gestão com a população, ainda, precisa ser fortificada. As pessoas não recebem nenhum tipo de treinamento em como agir em casos de desastres ou em como devem 
se preparar para minimizar os riscos. Porém, é importante destacar a cultura das comunidades quanto ao conhecimento adquirido por elas mesmas ao longo do tempo.

Com base nas visitas realizadas à cidade, ficou perceptível que a população conhece as áreas de risco do município, sabendo quais são as áreas que alagam e até onde a água pode chegar. Esse ensinamento é passado de pais para filhos, tanto que as crianças sabem as cotas exatas em que o nível do rio lguaçu pode atingir suas casas. Talvez pode ser afirmado que é devido essa cultura, em que os moradores da região "nascem sabendo" sobre as inundações, que a capacitação das pessoas não seja uma prioridade para os gestores municipais.

Além disto, também, foi observado juntamente à coordenação de proteção e defesa civil municipal, que há ações de resposta e recuperação que a própria comunidade possui. Existe uma organização local para ajudar as pessoas que são atingidas pelas cheias, em primeiro momento com a retirada e locomoção e depois com doações. Estas doações são recebidas tanto dos próprios moradores quanto dos municípios vizinhos, sendo que já aconteceu de terem que pedir para não doarem mais nada devido à alta quantidade que é recebida. Embora União da Vitória não possua nenhum Núcleo de Defesa Civil (NUDEC), os voluntariados são muito efetivos e sempre ocorrem quando é preciso.

Desta forma, é possível observar que tanto os gestores municipais estão em consonância com outros órgãos estaduais e federais, assim como a própria população, vêm evoluindo e se preparando cada vez mais para os desastres que atingem a cidade. Atualmente, o município de União da Vitória está no caminho para se tornar cada vez mais resiliente e minimizar os impactos deixados a cada inundação, sendo necessário que haja uma maior conexão entre as ações desenvolvidas pela gestão com as comunidades.

\section{Considerações finais}

Desde a primeira grande inundação, em 1983, foram realizadas diversas medidas que auxiliassem os gestores a entender como lidar com tal situação, estando entre elas o surgimento da Coordenadoria Municipal de Defesa Civil. Com cálculos extravasados, a ocorrência da inundação de 1992 deixou não só os moradores revoltados como também virou o olhar de diversos pesquisadores para entender o que estava acontecendo no município.

Diversos estudos que ajudassem a solucionar o problema das cheias foram elaborados desde então. No entanto, devido as condições físicas do município, ineficiência dos projetos e preços extremamente elevados de medidas estruturais, percebeu-se que os maiores investimentos deveriam se tratar de realocação de moradores e alterações das legislações de base. Essas ações são utilizadas até os dias de hoje, com a captação de novos recursos e monitoramento do Parque Ambiental construído após o evento de 2014.

Com esta análise histórica foi possível conhecer o que o município de União da Vitória passou desde o seu surgimento, compreendendo os diversos fatores que influenciam a ocorrência de eventos na cidade, sejam eles políticos, naturais, físicos ou sociais. Foi observado que o município possui uma forte cultura quanto a resposta aos desastres, devido a frequência elevada de eventos ocorridos. Organização setorial durante as 
inundações, presença de voluntariado e doações intermunicipais são exemplos das ações adotadas em União da Vitória.

No entanto, destaca-se a necessidade de se investir em medidas de prevenção e preparação das comunidades. A realização do mapeamento das áreas de risco e também, a capacitação da população que vive nas proximidades do rio Iguaçu, por meio de treinamento e simulados de emergência, é essencial para uma gestão de riscos eficiente. Deste modo, ressalta-se a importância para a resiliência a desastres em entender o passado das cidades, para só então compreender o presente e poder planejar o futuro.

\section{Agradecimentos}

O presente trabalho foi realizado com apoio da Coordenação de Aperfeiçoamento de Pessoal de Nível Superior

- Brasil (CAPES) - Código de Financiamento 001. Doutorado com vigência até 2022.

\section{Referências}

BI-CEPDEC. Business Intelligence. Coordenadoria Estadual de Proteção e Defesa Civil do Paraná. Relatório de Desastres do Paraná. 2020.

BRASIL. Construindo Cidades Resilientes. Ministério da Integração Nacional, 2013.

BRUNDTLAND, G. H., et al. Report of the World Commission on Environment and Development: Our Common Future. Oslo: United Nations, 1987. 187p.

CAMARGO CORREA, C. M; LEVASSEUR, J.; MANTOVANI, L. E. Avaliação das áreas atingidas pelas inundações e alagamentos em União da Vitória/PR, em junho de 2014. CENACID: União da Vitória, 2014.

CASTANHARO, G. Projeto HG-203: Análise Hidráulica de Alternativas Estruturais para Controle de Enchentes no Rio Iguaçu em União da Vitória/Porto União. Relatório Técnico. LACTEC e CEHPAR, 2005. $112 p$.

CASTANHARO, G.; BUBA, H. Revisão do comportamento hidráulico do Rio Iguaçu na região de União da Vitória e seu impacto na operação hidráulica dos reservatórios de Foz do Areia e Segredo. Revista Espaço Energia, n.8, 2008.

CENAD. Anuário brasileiro de desastres naturais. Brasília: Ministério da Integração Nacional. Secretaria Nacional de Defesa Civil, 2012.

CFP. Conselho Federal de Psicologia. Nota Técnica sobre Atuação da Psicologia na Gestão Integral de Riscos e de Desastres, relacionadas com a Política de Proteção e Defesa Civil. 2016.

CH2MHILL. Plano Diretor de Drenagem para a Bacia do Rio Iguaçu na Região metropolitana de Curitiba: Relatório. v. 1-10. SUDERHSA, 2002.

COHAPAR. Companhia de Habitação do Paraná. Após relocação de famílias, Copel recupera área em União da Vitória. COHAPAR, 2013.

CRED. Centre for Research on the Epidemiology of Disasters. Natural disasters 2017: Lower mortality, higher cost. Belgium: Université catholique de Louvain. CRED. USAID, 2018. 8p.

DALPÍCOLO, S. Entrevista ao Jornal Nacional sobre as Enchentes de 1992 em União da Vitória. Jornal Nacional, 1992. 
FOLKE, C.; CARPENTER, S.; ELMQVIST, T., et al. Resilience and sustainable development: building adaptive capacity in a world of transformations. Ambio, v. 31, n. 5, p. 437-440, 2002.

FRANÇA, V. de. Anatomia de uma Enchente. $2^{a}$ ed. COMDEC. SEED PR. Comissão de Alto Nível para Reconstrução. Grupo Executivo. União da Vitória: Editora Sulina Ltda, 1983.

FREITAS, C. M. et al. Desastres naturais e saúde: uma análise da situação do Brasil. Ciência \& Saúde Coletiva, v. 19, n. 9, p. 3645-3656, 2014.

FURTADO, J. R. (org). Gestão de Riscos de Desastres. Centro Universitário de Estudos e Pesquisas sobre Desastres. Florianópolis: CEPED UFSC, 2012. 14p.

GALINDO, E. F. Cidades e Suas Águas: a interface gestão urbana/gestão de recursos hídricos para a sustentabilidade ambiental. 2009. 197f. Tese (Doutorado em Desenvolvimento Urbano) - Universidade Federal de Pernambuco, 2009.

GIL, A. C. Como elaborar projetos de pesquisa. São Paulo: Atlas, 2002.

HONESKO, M. População revive as dores da enchente. União da Vitória: Vale, 2014.

IBGE. Instituto Brasileiro de Geografia e Estatística. União da Vitória. IBGE Cidades, 2020.

JANSSON, C. Porto União da Vitória sob o olhar de Claro Jansson. 1912.

KOBUS, B. Programa "Morar com Dignidade" quer realocar mais 100 famílias até o final de 2013. VALE, 2013.

KOMARCHESQUI, B. Sob a água, União da Vitória teme repetição da cheia de 92. Gazeta do Povo, 2014.

MALSCHITZKY, D. Relatos sobre as ações da Defesa Civil Municipal em entrevista cedido aos autores. União da Vitória, 2018.

MARANDOLA JR.; E.; HOGAN, D. J. Vulnerabilidades e riscos: entre geografia e demografia. Revista Bras. Est. Pop., v. 22, n.1, p.29-53, 2005.

MCGILL, R. Urban management checklist. Cities, v. 18, n. 5, p.347-354, 2001.

MORENO, E. L.; OYEYINKA, O.; MBOUP, G. State of the World's Cities 2010/2011: Bridging the Urban Divide. 2 ed. London: United Nations Human Settlements Programme (UN-HABITAT), 2010. 244p.

NHOATO, A. Relatos sobre as inundações de 1983, 1992 e 2014 em entrevista cedida aos autores. União da Vitória, 2018.

OLIVEIRA, M. de. et al. Capacitação dos Gestores de Defesa Civil para uso do Sistema Integrado de Informações sobre Desastres (S2iD). 2 ed. Florianópolis: Ministério da Integração Nacional, Secretaria Nacional de Defesa Civil, Universidade Federal de Santa Catarina, Centro Universitário de Estudos e Pesquisas sobre Desastres, 2013.

ONU. Organização das Nações Unidas. Como Construir Cidades Mais Resilientes: Um Guia para Gestores Públicos Locais. Nações Unidas: Genebra, 2012. 102p.

ONU. Organização das Nações Unidas. Construindo Cidades Resilientes: Minha cidade está se preparando. Tradução Sarah Marcela Chinchilla Cartagena. Florianópolis: Nações Unidas, 2010. 29 p.

PARANÁ. Copel investe na criação de parque em União da Vitória. Agência de Notícias do Paraná, 2014.

PINHEIRO, E. G. Gestão pública para a redução dos desastres: incorporação da variável risco de desastre à gestão da cidade. Editora Appris. Curitiba: 2015. 
PINHEIRO, E. G. Orientações para o planejamento em Proteção e Defesa Civil: Plano Estadual de Proteção e Defesa Civil. Curitiba: FUNESPAR, 2017.

PMUV. Prefeitura Municipal de União da Vitória. Base cartográfica das inundações de União da Vitória. Arquivos cedidos aos autores. 2018a.

PMUV. Histórico e Dados Gerais de União da Vitória. 2018b.

PMUV. Plano Diretor Municipal de União da Vitória. União da Vitória: Larocca Associados S/S LTDA, 2007.

PNRRC. Plataforma Nacional para a Redução do Risco de Catástrofes. Portugal: ISDR, 2017.

PNUD. Programa das Nações Unidas para o Desenvolvimento. BRA/12/017 - Fortalecimento da Cultura de Gestão de Riscos de Desastres no Brasil. Ministério da Integração Nacional. Secretaria Nacional de Defesa Civil, 2012. 58p.

PRZYSIEZNY, J. Relatos sobre os efeitos da enchente de 1983 na agricultura. In: Onde vocês estava? Enchente de 1983. União da Vitória, 2012.

ROCHA, P. S. M. Gestão em Áreas de Riscos de Enchentes: Um Estudo de Caso de União da Vitória. 2. ed. União da Vitória: UNIPORTO, 2014. v. 1.000. 172p.

SEC-CORPRERI. Sociedade de Estudos Contemporâneos - Comissão Regional Permanente de Prevenção contra Enchentes do Rio Iguaçu. Conhecendo e convivendo com as enchentes. Curitiba: SEMA/IAP, 1999.

SILVA, C. da. Apontamentos históricos de União da Vitória, 1768-1933. Coleção Adir Guimarães. 1. ed. (1000 exemplares). União da Vitória, 1933.

SULAIMAN, S. N. De que adianta? O papel da educação para a prevenção de desastres naturais. 2014. 291f. Tese (Doutorado em Educação) - Universidade de São Paulo. São Paulo, 2014.

TUCCI, C. E. M. Gestão de inundações urbanas. Logo Ministério das Cidades e Organização das Nações Unidas para a Educação, Ciência e Cultura (UNESCO). Global Water Partnership - World Bank. Porto Alegre: ABRH/RHMA, 2005.

TUCCI, C. E. M. Gestão de Águas Pluviais Urbanas. Capítulo 2. Rhama, 2013.

TUCCI, C. E. M.; VILLANUEVA, A. O. M. Controle de Enchentes de União da Vitória e Porto União. União da Vitória: COPRERI, 1997.

UNISDR.; CEPED PR. Estratégia Internacional das Nações Unidas para a Redução de Desastres. Centro de Estudos e Pesquisas sobre Desastres do Paraná. Desenvolvimento de Capacidades para Tornar as Cidades mais Resilientes: Minha Cidade está se preparando. Nações Unidas. Defesa Civil, 2010. 67p.

WOEHL, D. O conhecimento sobre cheias sugere a convivência responsável com o Rio Iguaçu. 2013.

WHOEL, D. Relatos sobre as inundações de 1983, 1992 e 2014 em entrevista cedida aos autores.

Presidente da SEC-CORPRERI. União da Vitória, 2018. 